\title{
STRATIGRAPHY OF THE CENTRAL PARTS OF THE PALAEOPROTEROZOIC TAMPERE SCHIST BELT, SOUTHERN FINLAND: REVIEW AND REVISION
}

\author{
YRJÖ KÄHKÖNEN
}

KÄHKÖNEN, YRJÖ 1999. Stratigraphy of the central parts of the Palaeoproterozoic Tampere Schist Belt, southern Finland: review and revision. Bulletin of the Geological Society of Finland 71, Part 1, 13-29.

The arc-type Palaeoproterozoic volcanic-sedimentary Tampere Schist Belt (TSB), close to the centre of the Svecofennian Orogen, comprises an E-W-striking major synform in its central parts. This paper presents a review of stratigraphy and proposes a revision of stratigraphic nomenclature of the central TSB. The stratigraphic columns differ from each other in different parts of the belt, and along-strike as well as limb-to-limb correlations are often problematic. However, certain generalizations are possible to make. The pillow-basalt-bearing Haveri formation with EMORB, not arc-type, affinities is the lowermost unit in the northern limb, and it is overlain by the turbidites of the Osara formation. The Haveri formation is regarded as the oldest unit of the TSB and it was evidently related to extension of Palaeoproterozoic crust before ca. $1.91 \mathrm{Ga}$. The Myllyniemi formation, characterized by mid-fan turbidites, is the lowermost unit in the southern limb. The Myllyniemi turbidites are thought to be broadly coeval with the Osara turbidites, and they were evidently deposited before the emplacement of the $1.904 \mathrm{Ga}$ subaerial dacite- and andesite-rich Koskuenjärvi formation of the northern limb. The turbidites of the Myllyniemi formation and those of the overlying Tuuliniemi formation show a general fining-upward trend. On the other hand, the proportion of arc-type volcanic rocks increases above the Myllyniemi formation and this evolution is accentuated by the growth of the ca. $1.89 \mathrm{Ga}$ Pulesjärvi-Kolunkylä complex of volcanic and sedimentary rocks that was in part subaerial. The subaqueous pyro-/volcaniclastic intermediate rocks among the turbidites of the southern limb possibly contain units coeval with the Koskuenjärvi formation. The 1.889 Ga Takamaa formation, rich in mafic volcanics, was formed after deposition of the sedimentary rocks (e.g. the Veittijärvi conglomerate) of the Pulesjärvi-Kolunkylä complex. The subaerial to shallow-water volcanic and sedimentary rocks of the Tohloppi-Tesoma-Kalkku area, in the southernmost TSB near Tampere, resemble the Pulesjärvi-Kolunkylä complex in age. Their present position gives an impression of a horizon below the Myllyniemi formation, but this is interpreted to be the result of early thrusting. Similarly, the fluvial-deltaic Mauri arenites with a predominantly felsic volcanic provenance are high in the generalized TSB stratigraphic column.

Key words: schist belts, metavolcanic rocks, metasedimentary rocks, stratigraphy, Paleoproterozoic, Tampere, Finland

Yrjö Kähkönen: Department of Geology, P.O. Box 11 (Snellmaninkatu 3), FIN00014 University of Helsinki, Finland.

E-mail: yrjo.kahkonen@helsinki.fi 


\section{INTRODUCTION}

The Palaeoproterozoic E-W-striking Tampere Schist Belt (TSB), in the centre of the Svecofennian Orogen (Fig. 1), is characterized by arc-type metavolcanic rocks and turbiditic metasedimentary rocks (Ojakangas 1986, Kähkönen 1987, 1989). Metamorphism culminated in low-pressure, lowtemperature amphibolite to transitional greenschist/amphibolite facies conditions (Kilpeläinen et al. 1994). The names of the supracrustal rocks are subsequently written without the prefix meta-. The TSB volcanic rocks dated so far have $\mathrm{U}-\mathrm{Pb}$ zircon ages of ca. 1.904-1.889 Ga (Kähkönen et al. 1989) while clastic zircons in the greywackes are mostly ca. 1.91-2.0 Ga in age and have an additional Archaean component (Huhma et al. 1991, Claesson et al. 1993). Also, an Archaean cobble in the Ahvenlammi conglomerate (p. 19) was reported by Kähkönen and Huhma (1993). To the north, the TSB is bounded by the ca. $1.88 \mathrm{Ga}$ Central Finland Granitoid Complex, and the granitoids intruding the belt are similar in age. The Pirkkala Migmatite Domain (also called the Vammala Migmatite Belt), south of the TSB, is dominated by gneisses and migmatites that were originally turbiditic sediments. According to Kähkönen (1989) and Nironen (1989) (but see also Simonen 1953), the TSB comprises a major E-Wstriking syncline with subvertical axial planes and subhorizontal axes in its central parts near Tampere. The northern limb is dominated by volcanic rocks, while the southern limb is rich in sedimentary rocks. Volcanic rocks are also abundant in the southernmost TSB near Tampere but at least a part of these rocks have U-Pb zircon age suggesting that younger rocks are situated below older (see p. 24). This feature probably indicates early thrusts and the belt should be considered a synform rather than a syncline.

The conventional stratigraphic concept of the TSB (Simonen 1953, 1980) is largely based on studies near Lake Näsijärvi and at Viljakkala (Fig. 1). According to this scheme, greywacke slates comprise the lowermost unit and are overlain by quartz-feldspar rocks (arkoses, greywackes and pyroclastic rocks). These are followed by mafic and intermediate volcanic rocks, conglomerates and associated sedimentary rocks (e.g. the Veittijärvi conglomerate), and finally by mafic volcanic rocks. A fundamental adjustment to this scheme is needed since the basalt-dominated Haveri formation (Fig. 1), contrary to the view of Simonen, underlies the nearby greywackes and mudrocks (Mäkelä 1980, Kähkönen \& Nironen 1994); otherwise, Simonen's concept is a plausible generalization (see Fig. 2). The Haveri formation is exceptional in the TSB because it contains abundant pillow lavas and because its mafic volcanics show EMORB (enriched mid-ocean ridge basalt), not arc-type, geochemical affinities (Kähkönen \& Nironen 1994).

This article presents a review and a partial revision of stratigraphic nomenclature of the TSB. The discussion proceeds from area to area and from profile to profile, not according to the interpreted ages. Since the paper is partly based on data from on-going studies, subsequent revisions are possible.

\section{REVISED STRATIGRAPHIC NOMENCLATURE}

Kähkönen (1989) informally divided the study profiles at Orivesi and Ylöjärvi into stratigraphic units. In this study a more formal stratigraphic classification is adopted. However, to emphasize the still informal status of the units, words such as "formation" and "member" are not written with a capital initial letter. The adjustments for the nomenclature of Kähkönen (1989) are given in Table 1 . The revised terms are used in Table 2 which presents simplified stratigraphic columns from different parts of the TSB.

\section{TSB STRATIGRAPHY PROFILE- BY-PROFILE AND AREA-BY-AREA}

The stratigraphic classification adopted here is essentially based on relatively well-exposed profiles in different parts of the belt. However, the contacts between the units are commonly hidden 


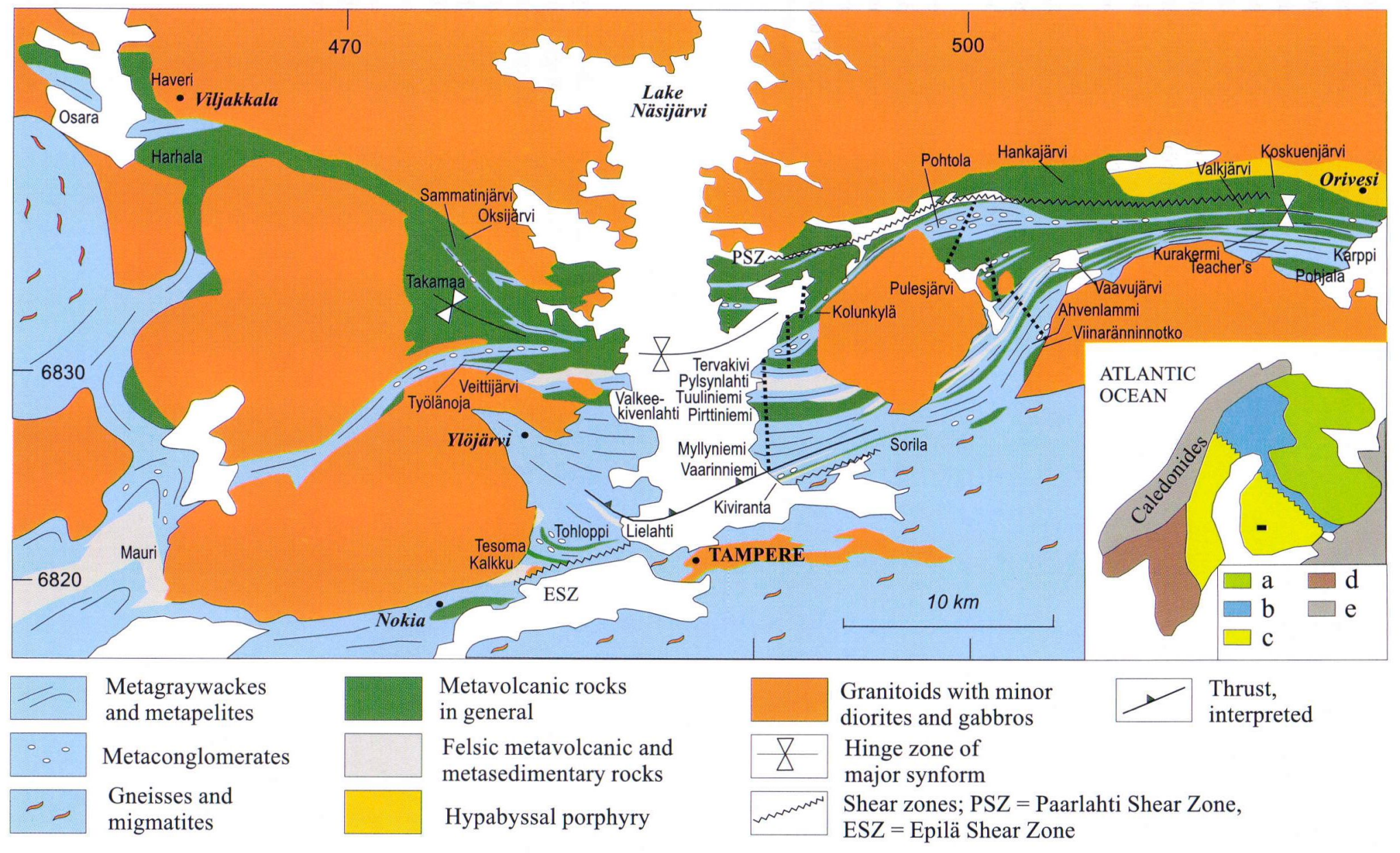

Fig. 1. Lithological map of the central Tampere Schist Belt with a simplified structural interpretation. Based on Kähkönen (1989), references therein, and on observations of the author. The dotted lines indicate the approximate positions of the Näsijärvi E and Pulesjärvi profiles. In the inset: a) Archaean craton; b) Karelian Domain; c) Svecofennian Orogen with the Tampere area as black rectangle; d) Post-Svecofennian Precambrian domains; $e$ ) Palaeozoic rocks. 


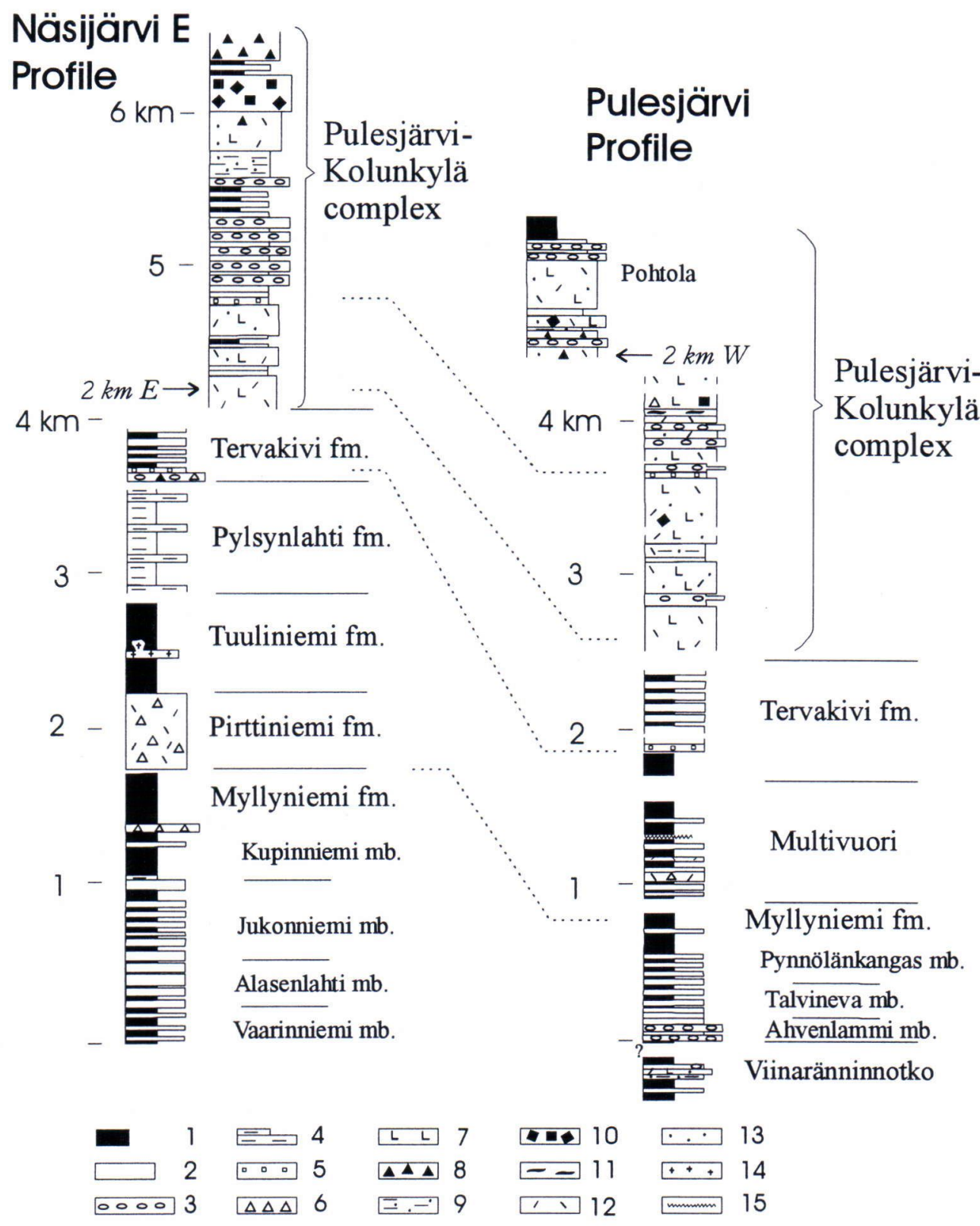

Fig. 2. Generalized stratigraphic columns of the southern limb of the Tampere Schist Belt in the Näsijärvi E and Pulesjärvi profiles. The illustration shows schematically approximated variations in bed thickness, grain size and sand-mud ratios; individual bed thicknesses e.g. in the Myllyniemi formation are not to true scale. Legend: 1) mudrocks; 2) greywackes; 3) conglomerates; 4) felsic to intermediate volcanic and sedimentary rocks, variations in grain size preliminary approximations; 5) trachytes and high-K rhyolites; 6) felsic to intermediate crystal and lithic tuffs, lapilli tuffs; 7) basaltic to andesitic lavas, in part pyro-/volcaniclastic; 8) basaltic to andesitic tuff breccias, agglomerates and lapilli tuffs; 9) mafic tuffs; 10) basaltic to andesitic matrix-supported tuff breccias or debris flows; 11) ignimbrites; 12) plagioclase-phenocrysts; 13) clinopyroxene-phenocrysts and -clasts (presently hornblende/uralite); 14) sills and subvolcanic intrusions; 15) mylonite. Based on Simonen and Kouvo (1951), Rautio (1987), Leveinen (1990), Kähkönen and Leveinen (1994), and observations of the author. 
Table 1. Adjustments of the stratigraphic terms of Kähkönen (1989).

\begin{tabular}{|c|c|}
\hline This study & Kähkönen (1989) \\
\hline \multicolumn{2}{|l|}{ AT ORIVESI } \\
\hline $\begin{array}{l}\text { Valkjärvi formation } \\
\text { Unnamed sedimentary rocks } \\
\text { Trachytic member } \\
\text { Shoshonitic member } \\
\text { Subalkaline member }\end{array}$ & $\begin{array}{l}\text { The sedimentary rocks overlying the Trachytic Unit } \\
\text { Trachytic Unit } \\
\text { Shoshonitic Unit } \\
\text { Subalkaline Unit }\end{array}$ \\
\hline Paarlahti Shear Zone & $\begin{array}{l}\text { The shear zone between the Intermediate } \\
\text { Unit and the Subalkaline Unit }\end{array}$ \\
\hline Koskuenjärvi formation & Intermediate Unit \\
\hline \multicolumn{2}{|l|}{ AT YLÖJÄRVI } \\
\hline \multirow[t]{2}{*}{ Takamaa formation } & Upper Volcanic Unit \\
\hline & $\begin{array}{l}\text { Felsic and intermediate rocks between the Lower Volcanic Unit and } \\
\text { the Upper Volcanic Unit in the northern limb of the major syncline; } \\
\text { now included in the uppermost parts of the Sammatinjärvi formation }\end{array}$ \\
\hline $\begin{array}{l}\text { Sammatinjärvi formation } \\
\text { Oksijärvi formation }\end{array}$ & $\begin{array}{l}\text { The Lower Volcanic Unit in the northern limb of the major } \\
\text { syncline; now divided into two units }\end{array}$ \\
\hline $\begin{array}{l}\text { Volcanic and sedimentary rocks } \\
\text { at Työlänoja }\end{array}$ & $\begin{array}{l}\text { The Lower Volcanic Unit in the southern limb of the major syncline } \\
\text { and the sedimentary and volcanic rocks between the Lower Volcanic } \\
\text { Unit and the Upper Volcanic Unit in the southern limb of the major } \\
\text { syncline }\end{array}$ \\
\hline
\end{tabular}

and the evidence is more or less fragmentary. In some cases correlation from profile to profile is possible, but this is not well founded everywhere due to scarcity of data.

The profiles, areas and units discussed are the Viljakkala area, the combined Näsijärvi E and Pulesjärvi profiles, the Vaavujärvi sill, the Hankajärvi area, the Orivesi area, the Ylöjärvi area, the Tohloppi-Tesoma-Kalkku area, and the arenites at Mauri (Fig. 1).

\section{Viljakkala area, northern limb}

In the northern limb at Viljakkala, the Haveri formation is the lowermost unit and is regarded as the oldest volcanic unit of the TSB. The Haveri formation is dominated by basalts that commonly show pillow structures. It also comprises cherts and sedimentary carbonates, as well as banded tuffs and tuffites which grade into sulphide-bearing mudrocks (Mäkelä 1980, Kähkönen \& Nironen 1994). The Haveri formation was probably extruded during extension of pre-1.91 Ga Palaeoproterozoic crust.

The contact is not exposed but the Haveri formation is very probably overlain by the turbiditic Osara formation. The greywackes of this formation largely resemble those of the Myllyniemi formation (see below) in chemical composition (Kähkönen \& Leveinen 1994). In general, the Osara turbidites may be coeval with the Myllyniemi turbidites.

The Harhala formation is composed mainly of arc-type andesitic, dacitic and rhyolitic volcanogenic rocks (Kähkönen \& Nironen 1994). The contact to the Osara formation is not exposed but the Osara turbidites are probably overlain by the Harhala volcanics.

\section{Näsijärvi E and Pulesjärvi profiles, southern limb}

On the eastern shore of Lake Näsijärvi, the wellexposed section from Vaarinniemi to Kolunkylä 
Table 2. Selected stratigraphic columns of the central TSB. The unit thicknesses are according to those in the study profiles. The columns are based on Seitsaari (1951), Simonen and Kouvo (1951), Mäkelä (1980), Rautio (1987), Kähkönen (1989, 1994), Kähkönen and Leveinen (1994), Kähkönen and Nironen (1994), and observations of the author.

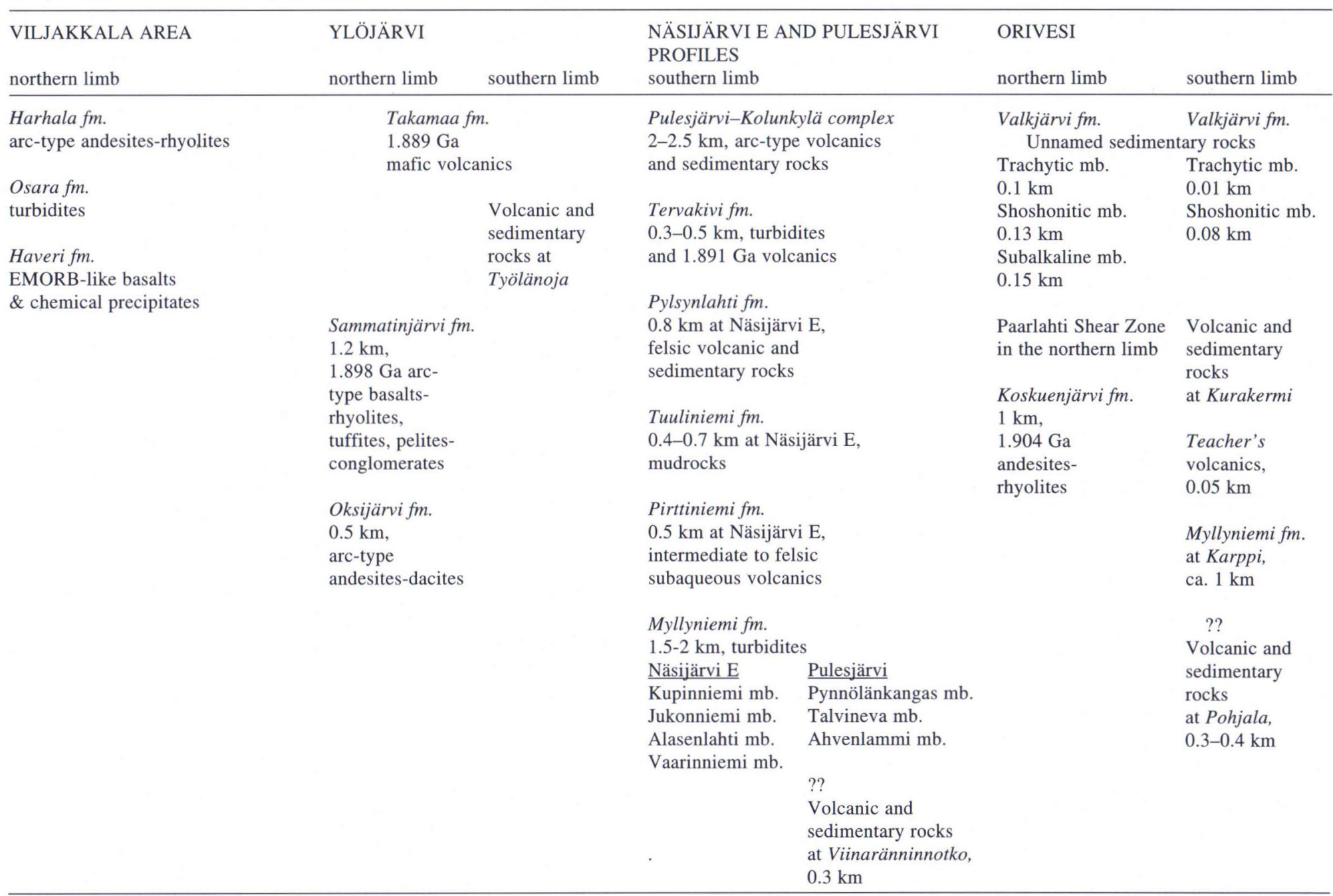


shows, with few exceptions, tops of strata to the north. This section comprises the Näsijärvi E profile (Figs. 1 and 2). The Pulesjärvi profile reaches from Viinaränninnotko in the south to Pulesjärvi and Pohtola in the north. The rocks in the southern part of the Pulesjärvi profile display more pronounced deformation than those in the northern part and those in the Näsijärvi E profile. This complicates correlation of the southern parts of the two profiles. In general, however, the profiles show an upward change from turbidite-dominated submarine environments to volcanic-dominated, in part, subaerial environments.

The Myllyniemi formation, as thick as $1.5-2 \mathrm{~km}$ (Table 2, Fig. 2), is the lowermost major unit. It is dominated by turbiditic sedimentary rocks and volcanic interbeds are scarce. The detritus was largely derived from felsic volcanic and plutonic rocks with minor quartzites and mudrocks. The uncertainty in the estimation of the thickness of the formation and its individual members is due to variation in the intensity of deformation and folding, particularly in the mudrock-dominated Kupinniemi and Pynnölänkangas members.

According to the data from the eastern shore of Lake Näsijärvi, the palaeocurrents of the Myllyniemi formation are northwesterly to westerly (Ojakangas 1986). The Alasenlahti and Jukonniemi members broadly resemble each other in being characterized by medium- to thick-bedded greywackes (and mudrocks) but the Alasenlahti greywackes are higher in silica than the Jukonniemi greywackes (Kähkönen \& Leveinen 1994). The lowermost (Vaarinniemi) member contrasts with the Alasenlahti and Jukonniemi members, as it has a higher proportion of mudrocks and thinner greywacke beds. The uppermost (Kupinniemi) member is overwhelmingly dominated by mudrocks. Most of the Myllyniemi turbidites represent midfan environments but the mudrock-rich uppermost parts are indicative of deeper-water environments.

In the Pulesjärvi profile, the Ahvenlammi member of the Myllyniemi formation, characterized by non-stratified or graded clast-supported quartz-rich pebbly conglomerates, is interpreted to have been deposited in submarine channels or canyons. The overlying Talvineva member, characterized by very thick- to medium-bedded greywackes, probably represents deposition in lower parts of the fan. The Alasenlahti member was possibly deposited on a fan separate from the fan on which the Ahvenlammi and Talvineva members were deposited. Evidence for this is that the Alasenlahti greywackes are slightly higher in silica than those of the latter members, and that thick-bedded quartzrich greywackes are absent at Sorila, halfway between Alasenlahti and Ahvenlammi (Fig. 1).

The volcanic and sedimentary rocks at Kiviranta (Fig. 1, not shown in Table 2) and at Sorila represent lateral extensions of the volcanic and sedimentary rocks of the Tohloppi-Tesoma-Kalkku area and the present position of these rocks in the southernmost TSB is thought to be due to early thrusts (p. 24, see also Kähkönen 1994). The succession at Kiviranta comprises mudrocks, trachytic feldspar-porphyritic and mafic to intermediate plagioclase \pm uralite-porphyritic volcanic rocks, tuffs and tuffites, conglomerates, and greywackes.

The volcanic and sedimentary rocks at Viinaränninnotko are situated southeast of the Ahvenlammi conglomerate in the southern Pulesjärvi profile (Figs. 1 and 2, see also Kähkönen 1994). The volcanic rocks, about $70 \mathrm{~m}$ in thickness, are enveloped by turbidites. They comprise massive to rarely stratified lithic-bearing crystal tuffs (deposited from subaqueous pyro-/volcaniclastic flows), mafic lavas and fine-grained stratified mafic tuffs or tuffites. The strata show younging towards the south. Because the ages of the volcanic rocks at Tohloppi-Tesoma-Kalkku and Kiviranta, also in the southernmost TSB, are interpreted to indicate early thrusting (see above and p. 24), the stratigraphic position of the succession at Viinaränninnotko is unclear. A position at the bottom of the rock column may be suspected because of the shoshonitic character of the crystal tuffs (Kähkönen 1994), a feature unusual to volcanic rocks low in typical arc successions. In addition, the black schists between the Ahvenlammi conglomerate and the Viinaränninnotko volcanics might comprise a favourable horizon for a detachment. However, although the area southwest of Viinaränninnotko is poorly known, the Viinaränninnotko supracrustal rocks are possibly not 
lateral equivalents of the Tohloppi-Kiviranta supracrustal rocks for two reasons. Firstly, Tohloppi-type conglomerates with abundant trachytic or high-K rhyolitic, pink feldspar-porphyritic cobbles are absent at Viinaränninnotko although they are found at Pohjanharju, ca. $10 \mathrm{~km}$ east of Kiviranta. Secondly, high-K feldspar-porphyritic strata are absent at Viinaränninnotko but are known at Kiviranta and near Tohloppi. The Viinaränninnotko supracrustal rocks might be interpreted to represent a unit stratigraphically low within (or below) the Myllyniemi formation but final conclusions are untimely.

The Pirttiniemi formation is a unit of pyro-/volcaniclastic rocks under- and overlain by mudrockdominated sedimentary units. It is about $0.5 \mathrm{~km}$ thick on the eastern shore of Lake Näsijärvi and ca. $5 \mathrm{~km}$ to the east it is well exposed in road cuts 1.5-2 km north of Sorila (Fig. 1). In its evident western extension at Valkeekivenlahti on the western shore of Lake Näsijärvi, it seems to be nearly $1 \mathrm{~km}$ thick, but the data are scarce. The Pirttiniemi formation is characterized by intermediate or felsic, massive to stratified tuffs and lapilli tuffs with variable proportions of plagioclase phenocrysts and lithic pyroclasts. In addition, fine- and evengrained interbeds are in places frequent. The presently lithic pyroclasts are fine-grained and may in part be originally vitric, but these are difficult to distinguish from originally fine-grained lithic pyroclasts. Particularly at Pirttiniemi, the lithic pyroclasts have commonly been sericitized, evidently before the eruption. The typical rocks of the Pirttiniemi formation are pyroclast-rich mass-flow deposits but it is not clear whether they should be interpreted as primary pyroclastic flow deposits, subaqueously-erupted volcaniclastic deposits or syn-eruptive resedimented deposits (cf. McPhie et al. 1993).

In the Pulesjärvi profile, intense deformation at and around Multivuori (2 km north of Ahvenlammi) makes stratigraphic correlation problematic. The rocks at Multivuori are characteristically turbiditic mudrocks with scarce thin-bedded graded greywackes (Leveinen 1990). Two units, up to $50 \mathrm{~m}$ thick, of intermediate stratified tuffs rich in plagioclase phenocrysts and with fine-grained interbeds also occur. Like the Pirttiniemi volcanics (see above), they are probably submarine pyroclast-rich mass-flow deposits. In addition to these, there are felsic schists (originally tuffs or tuffites) and mylonites.

The Tuuliniemi formation is composed of silty to clayey, mostly thin-bedded or laminated mudrocks, and there also occur rare felsic strata, obviously tuffs or tuffites in origin. Since the formation is known both on the eastern and western shores of Lake Näsijärvi, it extends more than $5 \mathrm{~km}$ along strike. The approximate thickness of the Tuuliniemi formation $(0.4-0.7 \mathrm{~km})$ is inexact for two reasons. First, observations (although rare) of southerly younging strata, in addition to the predominantly northerly younging directions, indicate isoclinal folds at Tuuliniemi. Second, plagioclaseand uralite-porphyritic subvolcanic rocks and sills are common among the Tuuliniemi mudrocks and intrude them. In any case, the Tuuliniemi formation complements the fining- and thinning-upward trend seen in the Myllyniemi formation.

The Pylsynlahti formation is poorly known and signs of deformation are in places pronounced. It is characterized by felsic or intermediate rocks that mainly seem to be of volcanic origin. In the north rocks relatively mafic in composition also occur.

The Tervakivi formation is $0.3-0.5 \mathrm{~km}$ thick (Kähkönen \& Leveinen 1994) and it can be traced for more than $15 \mathrm{~km}$ east of Lake Näsijärvi. The Tervakivi formation is dominated by a greywackerich turbiditic part which is underlain by a 20 $50 \mathrm{~m}$ thick pink feldspar-porphyritic high-K rhyolite with a ca. $1.891 \mathrm{Ga}$ U-Pb zircon age (H. Huhma, personal communication 1994). The rhyolite is, at least locally, underlain by intermediate to mafic pyro-/volcaniclastic rocks. The greywackes of the Tervakivi formation become less silicic upward in the succession, indicative of an increase in the proportion of mafic to intermediate volcanism in the source area. At the same time, the dominance of greywackes in the Tervakivi formation breaks off the general fining- and thinningupward trend of the combined Myllyniemi and Tuuliniemi turbidites.

The Pulesjärvi-Kolunkylä complex of volcanic and sedimentary rocks is $2-2.5 \mathrm{~km}$ thick. The 
complex contains more volcanic rocks near Lake Pulesjärvi than at Kolunkylä (Fig. 2). Intermediate to mafic lavas and felsic (in part pink in colour and trachytic or high-K rhyolitic in composition) to mafic pyro-/volcaniclastic rocks, as well as sandstones and conglomerates are common, but no pillow lavas are known. The sedimentary rocks at Kolunkylä include mudrocks and are mainly turbidites (Rautio 1987). At Pulesjärvi, on the other hand, pelites were not observed and the sandstones and conglomerates are apparently fluvial to shallow-water deposits (Leveinen 1990). The complex may be interpreted to comprise (an) emergent stratovolcano(es) with subaerial to submarine sedimentary aprons.

The supracrustal rocks at Pohtola, north of Lake Pulesjärvi (Figs. 1 and 2), differ from the rocks of the former units because they have gentle dips. In spite of this, they may be included in the uppermost parts of the Pulesjärvi-Kolunkylä complex. The volcanic rocks at Pohtola consist of mafic to intermediate tuff breccias, fine-grained tuffs and tuffites, and plagioclase-porphyritic lavas (Leveinen 1990). The sedimentary rocks include conglomerates, sandstones and mudrocks with mainly volcanic provenance. The lower sedimentary rocks at Pohtola are frequently crossbedded and possibly represent subaerial or shallow-water deposition while the uppermost sedimentary rocks at Pohtola are mudrocks indicative of deeper-water environment.

\section{Vaavujärvi sill}

The Vaavujärvi sill lies between the Pulesjärvi profile and the study areas at Orivesi. It is about $0.4 \mathrm{~km}$ thick at maximum and extends about $6 \mathrm{~km}$ in a WSW-ENE direction (Seitsaari 1951, Kähkönen 1989). Because the sill disappears abruptly in the WSW but thins gradually towards the ENE, it was probably fed from the WSW. Stratigraphically, the Vaavujärvi sill lies below the Tervakivi formation but above the Myllyniemi formation, the Multivuori volcanics and the lateral equivalents of the Teacher's volcanics at Orivesi (Fig. 1). The sill is characterized by massive high-K trachyandesites rich in plagioclase pheno- crysts and with minor phenocrysts of pyroxene (presently amphibole) and hornblende. Finegrained contact zones are found along the northern and southern margins.

\section{Hankajärvi area}

The Hankajärvi area is characterized by mafic volcanic rocks but includes intermediate and felsic volcanics as well. The mafic-rich unit has a maximum thickness of about $1 \mathrm{~km}$, and can be traced on aeromagnetic maps for ca. $5 \mathrm{~km}$ in an E-W direction. Indisputable observations on younging direction are lacking but the volcanic strata seem to young to the south. To the north the mafic-rich unit is bounded by plagioclase-porphyritic intermediate volcanic rocks (including a minor conglomerate or tuff breccia), and in the south the Paarlahti Shear Zone (Fig. 1) makes correlation problematic.

The mafic volcanics at Hankajärvi are characterized by uralite \pm plagioclase-porphyritic rocks. Massive lavas, tuff breccias, lapilli tuffs, crystal tuffs and a conglomerate have been identified; fine-grained tuffs seem to be absent.

\section{Orivesi area}

In the northern limb of the major synform at Orivesi, the Koskuenjärvi formation is the lowermost unit. It seems to be ca. $1 \mathrm{~km}$ thick and extends up to $10 \mathrm{~km}$ in an $\mathrm{E}-\mathrm{W}$ direction. With a $\mathrm{U}-\mathrm{Pb}$ zircon age of $1904 \pm 4 \mathrm{Ma}$ (Kähkönen et al. 1989), it is the oldest volcanic unit dated thus far in the TSB. The Koskuenjärvi formation is characterized by massive to stratified plagioclase-porphyritic high-K dacites and andesites. Felsic rocks are relatively abundant but mafic volcanics are rare. The volcanic rocks are largely of pyroclastic origin. Subaerial to shallow-water environments are evident because epidote-rich fragments, probably originally pumice (see Laitakari 1980), are quite common and because turbidite interbeds are rare or absent.

The Valkjärvi formation is separated from the Koskuenjärvi formation by the E-W-striking Paarlahti Shear Zone. Largely based on chemical com- 
position, the Valkjärvi formation is divided into three volcanic members: the Subalkaline member (oldest), the Shoshonitic member, and the Trachytic member (youngest). The Subalkaline member is presently identified only in the northern limb, while the Shoshonitic member and the Trachytic member are known in both limbs (Kähkönen 1989). In addition to these, two unnamed sedimentary units are included in this formation.

The Subalkaline member is about $150 \mathrm{~m}$ thick in the studied profile. The volcanic rocks are characteristically of pyroclastic origin (tuffs and lapilli tuffs), but the unit also includes a massive stratum of uralite+plagioclase-porphyritic lava or sill, graded tuffites or greywackes as well as mudrocks. The felsic rocks in the northern part, towards the Paarlahti Shear Zone, display thin banding that is largely attributed to deformation. In general, the strata of the Subalkaline member represent subaqueous depositional environments distal from volcanic centres.

The Shoshonitic member is separated from the Subalkaline member by 5-10 metres of thin-bedded silty mudrocks or tuffites that indicate waning volcanic activity. It is ca. $130 \mathrm{~m}$ and ca. $80 \mathrm{~m}$ thick in the northern and southern limbs of the synform, respectively. There are massive and fragmental porphyritic lavas as well as tuff breccias, lapilli tuffs, and fine-grained tuffs or tuffites. A five metre-thick trachytic stratum of lapilli- and crystal-bearing tuff also occurs in this unit.

The Trachytic member is ca. $100 \mathrm{~m}$ and ca. $10 \mathrm{~m}$ thick in the northern and southern limbs of the synform, respectively. Seitsaari (1951) traced this unit of pink feldspar porphyry for 10-11 km in an E-W direction. It is not clear whether these rocks are of welded pyroclastic or lava origin. They occasionally exhibit a pillow-like structure that might be a result of lava flow or rheomorphism (i.e. secondary flowage of welded tuff). The wide lateral extent relative to thickness would suggest that these rocks were originally pyroclastic flow deposits rather than lavas but they might also be like the extensive silicic lavas discussed by Henry and Wolff (1992). A microscopic fragmental texture that is possibly indicative of a pyroclastic origin is present, but dark pyroclasts, typical of pyroclastic flow deposits, are absent. In this respect they could resemble the massive pyroclastic flow deposits described by Green and Fitz (1993). In any case, these pink feldspar porphyritic rocks are not late dykes because similar clasts abound in the overlying conglomerates (see below).

Around the hinge zone of the major synform, the Trachytic member changes upward into an unnamed unit that constitutes a fining-upward succession from volcanogenic conglomerates to greywackes and finally to graded siltstones and mudstones. Pink cobbles and pebbles resembling the rocks of the Trachytic member are common. These sedimentary rocks, together with the Shoshonitic member and the Trachytic member, may represent eastern extensions of the Pulesjärvi-Kolunkylä complex.

In the southern limb of the major synform at Orivesi, the lower parts are dominated by turbiditic sedimentary rocks. Volcanic interbeds, mostly deposited from subaqueous pyro-/volcaniclastic flows, do occur and the proportion of volcanic rocks increases upward in the succession. A detailed division of the rocks into strictly defined stratigraphic units is not possible due to the scarcity of data.

The volcanic and sedimentary rocks at Pohja$l a$, in the southernmost part of the belt, show younging to the south and comprise a $300-400 \mathrm{~m}$ thick unit of greywackes, mudrocks, tuffs, lithicrich crystal tuffs, conglomerates and porphyritic sills (Kähkönen 1994). The crystal tuffs are high$\mathrm{K}$ basaltic andesites with arc affinity. The successions at Pohjala and Viinaränninnotko might belong to the same horizon although their volcanics show differences: both lie in the southernmost parts of the TSB and have southerly younging directions. Considering the discussion on the stratigraphic position of the Viinaränninnotko supracrustal rocks (p. 19), the position of the succession at Pohjala may be similarly questionable.

The turbidites at Karppi, between the Pohjala succession and the Teacher's volcanics (see below), show northern younging directions and comprise a unit about $1 \mathrm{~km}$ in thickness. The rocks include greywackes, mudrocks and possibly minor tuffs or tuffites. Based on low-altitude aero- 
geophysical maps, sulphide- and graphite-bearing mudrocks may also be present. The greywackes are in many cases rich in quartz, high in silica and medium- to very thick-bedded (Kähkönen \& Leveinen 1994). In general, the Karppi turbidites are probably lateral equivalents of the Myllyniemi formation.

The Teacher's volcanics are less than $50 \mathrm{~m}$ thick in the study area, and on the map of Seitsaari (1951) this unit can be traced for $10-15 \mathrm{~km}$ in an E-W direction. The rocks are characteristically stratified or faintly fragmental lithic-bearing crystal tuffs and lapilli tuffs with $20-30$ vol\% of plagioclase phenocrysts (Kähkönen 1994). They are evidently subaqueous pyroclast-rich mass-flow deposits. Most of the rocks have hornblende as a major mineral, and minor garnet. According to chemical composition, the Teacher's volcanics are arc-type medium-K to high- $\mathrm{K}$ intermediate rocks.

The turbidites between the Teacher's volcanics and the volcanic rocks at Kurakermi (see below) comprise a unit about $0.2 \mathrm{~km}$ in thickness. They are characterized by mudrocks and, together with the underlying Karppi turbidites, indicate a finingupward trend similar to that seen in the turbidites from Myllyniemi to Tuuliniemi in the Näsijärvi E profile.

Data on the Kurakermi volcanics are scarce but, together with the interlayered and the overlying sedimentary rocks, they comprise a unit $0.3-0.4$ $\mathrm{km}$ thick. They are mostly intermediate in composition and characterized by massive to stratified lithic-bearing tuffs with $20-40 \mathrm{vol} \%$ of plagioclase phenocrysts. Lapilli tuffs and tuff breccias are less common. Evidently, these rocks were originally subaqueous pyroclast-rich mass-flow deposits. In addition, turbidites, fine-grained tuffs and tuffites, and a few mafic tuffs are present. As interpreted from the map of Seitsaari (1951), the proportion of turbidites increases to the west.

The strata north of the Kurakermi rocks just discussed include equivalents of the Valkjärvi formation because volcanic rocks similar to those of the Shoshonitic and Trachytic members are present. In addition, conglomerates, greywackes and mudrocks occur close to the hinge zone of the major synform.

\section{Ylöjärvi area}

In the northern limb at Ylöjärvi, the Oksijärvi formation is regarded as the lowermost unit although deformation and shear zones cause problems. The formation is about $0.5 \mathrm{~km}$ thick in the study area and it is characterized by massive to fragmental plagioclase-porphyritic andesites and dacites (samples 260-269 in Kähkönen 1989). This unit petrographically resembles the Koskuenjärvi formation but, compared with the latter, andesites tend to be more common and, in general, the rocks are of medium-K type rather than of high-K type.

The Sammatinjärvi formation is separated from the former unit by 5-10 metres of silty to clayey mudrocks. It is about $1.2 \mathrm{~km}$ wide across strike but shear zones complicate the stratigraphy. In the lower parts of the Sammatinjärvi formation the rocks are mainly pyroclastic or volcaniclastic in origin, with rare lavas or sills. They range from basalts to rhyolites in composition. The U-Pb zircon age of $1898 \pm 4 \mathrm{Ma}$ (Kähkönen et al. 1989) is from a dacitic stratum relatively high in the lower part of the Sammatinjärvi formation.

In the upper part of the Sammatinjärvi formation the rocks are first mainly intermediate tuffites. These grade upwards into intermediate to felsic rocks that include greywackes, mudrocks, conglomerate, tuffites, and rare crystal/lithic tuffs and lapilli tuffs. These rocks locally display pronounced deformation, and encompass at least one shear zone.

The Takamaa formation occupies a position in the hinge zone of the major synform. It is composed of volcanic rocks that comprise both pyroclastic and lava rocks. No pillow lavas have been identified. The volcanic rocks are dominated by basalts and basaltic andesites and have tectonomagmatic affinities transitional between arc and EMORB or WPB (within-plate basalt) types (Kähkönen 1989). The Takamaa formation, with a U-Pb age of $1889 \pm 5 \mathrm{Ma}$ (Kähkönen et al. 1989), is the youngest volcanic unit dated so far in the TSB.

In the southern limb, the volcanic and sedimentary rocks at Työlänoja contain lateral extensions of the Veittijärvi conglomerate (Sederholm 1897) 
which, together with the related greywackes and mudrocks, separates the "Lower Volcanic Unit" of Kähkönen (1989) from the Takamaa formation. The conglomerate and associated sedimentary rocks have predominantly volcanic provenance and are interpreted to have been deposited in submarine channels of a turbidite fan (see also Rautio 1987). In addition to graded greywackes and mudrocks, the ca. $0.5 \mathrm{~km}$ thick succession above the conglomerate at Työlänoja contains mafic, intermediate and felsic volcanics as well as sills and subvolcanic rocks. South of Työlänoja, the volcanics (below the conglomerate) comprise a ca. $100 \mathrm{~m}$ thick unit of massive low-K to medium-K dacites and andesites which are underlain by mudrocks. At Mastosjärvi, $5 \mathrm{~km}$ east of Työlänoja, the volcanic rocks below the Veittijärvi conglomerate contain trachyandesites that resemble the rocks of the Shoshonitic member of the Valkjärvi formation (at Orivesi) in composition.

\section{Tohloppi-Tesoma-Kalkku area}

The structural position of the supracrustal rocks of the Tohloppi-Tesoma-Kalkku area, in the southernmost part of the TSB near Tampere, is seemingly out of place for two reasons. First, a $\mathrm{U}-\mathrm{Pb}$ zircon age of ca. $1891 \mathrm{Ma}$ for a rhyolitic lithic tuff from Tesoma indicates that they are roughly coeval with the ca. 1891 Ma Tervakivi formation (H. Huhma, personal communication 1994) that occupies a position in the upper part of the stratigraphic column (see Fig. 2). Second, the Tesoma rhyolite is also younger than the youngest clastic zircons in the Myllyniemi greywackes $(1915 \pm 30 \mathrm{Ma}$ in sample A57 from the western shore of Lake Näsijärvi, Claesson et al. 1993) and their probable equivalents at Nokia (1907 \pm 15 Ma, Huhma et al. 1991). The contradiction is interpreted to indicate early thrusting.

Based on stratigraphic top observations, the supracrustal rocks at Tohloppi-Tesoma-Kalkku comprise an anticline with a mainly E-W striking subvertical axial plane and a gently plunging fold axis. The hinge zone of a related syncline may be outlined in the poorly exposed area northeast of Tohloppi, at Lielahti. In addition, a minor syncline is present in the southernmost part at Kalkku. Well-exposed strata in the northern limb of the anticline approach $1 \mathrm{~km}$ in total thickness. In the southern limb, a total thickness of 0.5 to $0.7 \mathrm{~km}$ is suggested but the estimate is inaccurate because of deformation and scarcity of stratified rocks.

The Tesoma supracrustal rocks occur around the hinge zone of the anticline and are composed of mudrocks, tuffites, stratified lithic and crystal tuffs, and lapilli tuffs. In the northern limb, towards Tohloppi, the rocks change across strike from graded greywackes into fluvial/alluvial conglomerates, sandstones and mudrocks. These sedimentary rocks are first overlain by a subaerial or shallow-water trachyandesite lava sequence as thick as $280 \mathrm{~m}$, and then by another unit of fluvial/alluvial conglomerates and sandstones (Kähkönen 1994). The strata above the latter unit are not exposed.

In the southern limb, towards Kalkku, the Tesoma supracrustal rocks are first overlain by crossbedded, rarely graded sandstones and siltstones, and then by pinkish high-K rocks that are interpreted as arenites with a predominantly felsic volcanic provenance. These Kalkku arenites are of two types; cross-bedded sandstones and more massive sandstones with infrequent stratification. The cross-bedded sandstone is characteristic of the lower Kalkku arenites while the upper part is dominated by the massive type. The cross-bedded arenites have a few interbeds of conglomerate, non-bedded sandstone, and pebble trails, and were likely deposited in fluvial environments. The massive rocks are interpreted as arenites because they display, although rarely, stratification, cross bedding, and contain pebbles. In addition, they resemble the cross-bedded Kalkku arenites in petrography and geochemistry (unpublished data of the author). The Kalkku "porphyry", dated at $1889 \pm 19$ Ma by Kähkönen et al. (1989), is also evidently a massive arenite. Therefore, this date gives the age of the rocks in the source area.

\section{Mauri arenites}

The Mauri arenites, $25-40 \mathrm{~km}$ west of Tampere (Fig. 1), comprise an up to $2-2.5 \mathrm{~km}$ thick unit of pinkish cross-bedded sandstones with mainly 
west to east palaeocurrents and are interpreted to have been deposited in fluvial-deltaic environments (Matisto 1968). The Mauri arenites contain, on the average, about 20 vol\% large (diameter up to $2-4 \mathrm{~mm}$ ) clasts of quartz, plagioclase and potassium feldspar in total. The matrix is finegrained and shows pronounced recrystallization. Notwithstanding recrystallization, the matrix is interpreted to have originally been largely composed of fine-grained and porphyritic rock fragments; i.e. of volcanogenic clasts (observations by the present author). Therefore, and noting the small proportion of crystal clasts, the sandstones are lithic arenites rather than arkoses (cf. Matisto 1968). Based on the interpreted volcanogenic clasts, the provenance was dominated by felsic volcanic rocks but evidently included granitoids as well. Zircon in the Mauri sandstone is about $1.9 \mathrm{Ga}$ old (Matisto 1968). The Mauri arenites pass upwards into mudrocks that are poorly known but may constitute a unit more than $1 \mathrm{~km}$ thick. The considerable thickness of these mudrocks probably indicates basin subsidence, but speculations on the reasons are untimely with the scarce data available.

Matisto (1977) mentioned that the easternmost extensions of the Mauri arenites are found close to Tohloppi, about $15 \mathrm{~km}$ to the east of the Mauri exposures. Based on similarities in lithofacies, petrography and geochemistry (unpublished data of the author), it is probable that the Kalkku arenites represent extensions of the Mauri arenites and that the two arenites were closely connected during deposition.

According to unpublished data of the author, the source areas of the Mauri and Kalkku arenites are evidently dominated by volcanic rocks largely similar to those of the high-K rhyolite of the Tervakivi formation, the Trachytic member of the Valkjärvi formation and the trachytic or high-K rhyolitic units of the Pulesjärvi-Kolunkylä complex. Considering the thickness of the Mauri arenites, high-K felsic volcanics with an iron-enrichment affinity were evidently volumetrically a more important component in the ca. $1.89 \mathrm{Ga}$ volcanism than what is deduced from their present proportion in the Pulesjärvi-Kolunkylä complex.

\section{CORRELATIONS}

Although the information is in part lacking, it is evident that the belt can be reasonably divided into separate units and that some of the units can be traced along strike and also correlated from limb to limb of the major synform. The Myllyniemi formation extends at least from the western shore of Lake Näsijärvi to Karppi at Orivesi. The Osara formation in the Viljakkala area may also belong to its counterparts. In addition, the turbiditederived gneisses and migmatites in the Pirkkala Migmatite Domain to the south mostly resemble the Myllyniemi turbidites in chemical composition (Lahtinen 1996) and might largely represent the extensions of the latter. Probably all these turbidites were largely deposited before the 1.905$1.89 \mathrm{Ga}$ subduction-related volcanism because their youngest clastic zircons are ca. 1.91 Ga old (p. 14). Consequently, they do not represent forearc deposits of the 1.905-1.89 Ga Tampere arc because forearc sediments are typically derived from adjoining arc massifs.

Correlation of the subaqueous pyroclast-rich mass-flow deposits in the southern limb of the major synform is in part possible but in part waits for more studies. In particular, correlation of the successions at Viinaränninnotko and Pohjala to the supracrustal rocks at Tohloppi-Tesoma-Kalkku, Kiviranta and Sorila are problematic without U-Pb zircon ages (see pages 19-20 and 22).

Based on the frequent occurrence of hornblende and garnet in the Teacher's volcanics, this unit can be distinguished from the volcanogenic strata at Kurakermi and Multivuori as well as from the Pirttiniemi formation. As interpreted from the map of Seitsaari (1951), the Teacher's volcanics may disappear $10-15 \mathrm{~km}$ west of the type localities at Orivesi.

The Pirttiniemi formation can evidently be traced for 10 kilometres near Lake Näsijärvi but its correlation to the Pulesjärvi profile and east of it is not self-evident at the moment. Speculatively, the volcanics at Multivuori might be more closely correlated to those at Kurakermi (Orivesi) than to the Pirttiniemi formation but all these rocks may also comprise separate units. However, they 
are probably close to each other in age.

The Shoshonitic and Trachytic members of the Valkjärvi formation at Orivesi and the Veittijärvi conglomerate at Ylöjärvi (with related sedimentary and volcanic rocks) possibly represent extensions of the Pulesjärvi-Kolunkylä complex. Accordingly, this complex would be about $40 \mathrm{~km}$ wide in an E-W direction. Further studies in different parts of the complex are necessary to determine whether one or several volcanoes were present.

In the northern limb, the $1.904 \mathrm{Ga}$ Koskuenjärvi formation largely resembles and might be coeval with the Oksijärvi formation. However, considering the volcanic environment and the differences in composition (Kähkönen 1989), these formations constitute separate units rather than a single 40$50 \mathrm{~km}$ wide and $0.5-1 \mathrm{~km}$ thick coherent formation.

Limb-to-limb correlations are clearest at Orivesi where the Shoshonitic and Trachytic members of the Valkjärvi formation are identified in both limbs of the major synform. At Ylöjärvi, in contrast, trachyandesitic rocks similar to those below the Veittijärvi conglomerate in the southern limb are not identified in the northern limb (Kähkönen 1989). In addition, the conglomerate in the uppermost part of the Sammatinjärvi formation in the northern limb does not contain pink feldspar-porphyritic pebbles and cobbles that are common in the Veittijärvi conglomerate in the southern limb. However, it is possible that these conglomerates are approximately coeval because differences in clast composition may be due to abrupt lateral facies changes in a volcanic terrain.

Correlation of the Koskuenjärvi formation to the volcanic units in the southern limb of the major synform is complicated by the Paarlahti Shear Zone. It is still tempting to suggest that some units of submarine pyroclast-rich mass-flow deposits in the southern limb are coeval with the $1 \mathrm{~km}$ thick, evidently subaerial Koskuenjärvi formation. In island arcs, subaerial pyroclastic flows may change into subaqueous pyroclast-rich flows within a few kilometres from the eruption centres and flow hundreds of kilometres (e.g. Cas \& Wright 1987, pp. 271-276).

\section{DISCUSSION}

The position of the relatively young TohloppiTesoma-Kalkku supracrustal rocks in the southernmost TSB seems to indicate the presence of a thrust (p. 24). Consequently, thrusts might be considered possible in other parts of the TSB as well. For instance, the Näsijärvi E profile, although well exposed, might not necessarily be continuous because of unidentified thrusts, and hence it might include some repetition of strata due to thrusting. However, significant repetition of strata is not evident in the Näsijärvi $\mathrm{E}$ profile because the distinguished units have individual sedimentological, volcanological and chemical characteristics. Therefore, the presence of several thrusts is not probable in this profile.

The depositional environments of the Myllyniemi and Tuuliniemi formations show a general deepening-upward trend. Considering the thickness of these units, the trend is probably not caused by channel filling, channel migration or eustatic sea level changes but rather by tectonic subsidence of the basin floor. The possible reasons for the subsidence may be extension, transtension or thrust loading. Because the subsidence was active before the ca. $1.89 \mathrm{Ga}$ volcanism that obviously preceded the interpreted thrusting, it was probably not caused by loading of the thrusts. Whether extension or transtension was a more probable reason is not clear.

The volcanic and sedimentary rocks at Tohloppi-Tesoma-Kalkku, Kiviranta and Sorila, in southernmost parts of the TSB, are roughly coeval with the Pulesjärvi-Kolunkylä complex. The Tohloppi succession resembles the andesite-, conglomerate- and sandstone-rich subaerial parts near Lake Pulesjärvi. However, units similar to that at Kalkku, characterized by cross-bedded and massive arenites with predominantly high-K felsic volcanic provenances, seem to be absent at Pulesjärvi and Kolunkylä. The Kalkku arenites are probably lateral extensions of the Mauri arenites. The thickness of the latter enchance the volumetric significance of high-K rhyolitic and trachytic volcanism with iron enrichment in the TSB.

The Pirkkala Migmatite Domain may largely 
represent the accretionary prism (or subduction zone complex) related to the Tampere arc. It is dominated by turbidites but is relatively rich in sulphide- and graphite-bearing mudrocks that are not common in the TSB. The domain comprises a few basalt units with MORB to WPB affinities that probably approach the Haveri formation in age (Lahtinen 1996). At least a part of the sulphide- and graphite-bearing mudrocks are evidently linked with these basalts and were deposited before ca. $1.905 \mathrm{Ga}$. Arc-type volcanic rocks are absent or very rare in the migmatite domain but some of the sedimentogenic rocks resemble the volcanic-related sedimentary rocks in the upper part of the TSB stratigraphic colum (Lahtinen 1996) and would thus be about $1.90-1.89 \mathrm{Ga}$ in depositional age. Therefore, the Pirkkala Migmatite Domain probably comprises mainly sedimentary (and minor mafic volcanic) rocks older than ca. 1.905 Ga but has, although less abundat, also supracrustal rocks deposited at 1.90-1.89 Ga. In addition, the migmatite domain might comprise Palaeoproterozoic rocks that are considerably older than $1.91 \mathrm{Ga}$ because the accretionary prisms of young arc systems are largely composed of rocks significantly older than the related Recent volcanic arcs (e.g. Moore et al. 1991).

The provenace of the Myllyniemi turbidites is problematic because rocks with ages of ca. 1.91$2.0 \mathrm{Ga}$, i.e. equal to the ages of clastic zircons in these turbidites, are rare in the Svecofennian Orogen. Note also that zircons with similar ages are common in Svecofennian greywackes outside the TSB (Huhma et al. 1991, Claesson et al. 1993). Possible candidates include the 1.92-1.93 Ga rocks near the Archaean-Proterozoic boundary in east-central Finland (e.g. Kousa et al. 1994), the $1.95 \mathrm{Ga}$ Knaften granitoid in northern Sweden (Wasström 1993) and the $2.03 \mathrm{Ga}$ Njurunda granite in central Sweden (Welin et al. 1993). The ca. 1.95-1.96 Ga ophiolites in eastern Finland (Kontinen 1987, Peltonen et al. 1996) may also be considered but they did not probably feed large amounts of clastic zircon into greywackes. Also, considering the northwesterly to westerly palaeocurrents in the Myllyniemi turbidites, the ca. 2.0 $\mathrm{Ga}$ old rocks in Russia and Belorussia (e.g.
Bogdanova et al. 1994) might be possible source areas. Finally, Lahtinen and Huhma (1997), based on isotopic and geochemical data, suggest that evolved crust, developed during the Palaeoproterozoic, existed in the area of the present Central Finland Granitoid Complex already at ca. 2.0 Ga. It should, however, be underlined that any preserved rocks of this protocrustal "Fairyland" are not known in central Finland.

A tentative generalized evolution of the central TSB is envisaged as follows. The Haveri formation was formed during extension of pre-1.91 Ga Palaeoproterozoic crust. Evidence of a pre-1.91 Ga crust is seen in the 1.91-2.0 Ga clastic zircons of the Myllyniemi greywackes. The depositional environments of the Myllyniemi and Tuuliniemi formations show a general deepening-upward trend that is attributed to basin subsidence. On the other hand, as shown by the Pirttiniemi formation, Teacher's volcanics and Kurakermi volcanics, the amount of arc-type volcanic rocks begins to increase upwards in the succession. Some of the subaqueous pyro-/volcaniclastic units among the Myllyniemi-Tuuliniemi turbidites may be coeval with the $1.904 \mathrm{Ga}$ subaerial Koskuenjärvi formation. The upward change from submarine environments to volcanic-dominated, in part subaerial environments is accentuated by the growth of the Pulesjärvi-Kolunkylä complex about $1.89 \mathrm{Ga}$ ago. The Takamaa formation, with transitional tectonomagmatic affinities, and the thickness of the Mauri arenites and overlying mudrocks may indicate extension after the formation of the PulesjärviKolunkylä complex.

ACKNOWLEDGMENTS. A part of the new data discussed here were collected during studies related to the project "Global Geoscience Transects", supported by the Geological Survey of Finland and the Academy of Finland. Financial support from the Wilhelm Ramsay and Th. G. Sahama Memorial Foundation is also gratefully acknowledged. In addition, the observations made in 1992-1995 during the field mapping courses of the Department of Geology, University of Helsinki were valuable. I would also like to thank Jussi Leveinen and Tapio Koistinen for comments and 
discussions, and Hannu Huhma for information on zircon dates. Finally, reviews by Richard W. Ojakangas and Pär Weihed significantly improved the manuscript.

\section{REFERENCES}

Bogdanova, S.V., Bibikova, E.V. \& Gorbatschev, R. 1994. Palaeoproterozoic U-Pb zircon ages from Belorussia: new geodynamic implications for the East European Craton. Precambrian Research 68, 231-240.

Cas, R.A.F. \& Wright, J.V. 1987. Volcanic Successions. Modern and Ancient. London: Allen \& Unwin. 528 p.

Claesson, S., Huhma, H., Kinny, P.D. \& Williams, I.S. 1993. Svecofennian detrital zircon ages - implications for the Precambrian evolution of the Baltic Shield. Precambrian Research 64, 109-130.

Green, J.C. \& Fitz, T.J. 1993. Extensive felsic lavas and rheoignimbrites in the Keweenawan Midcontinent Rift plateau volcanics, Minnesota: petrographic and field recognition. Journal of Volcanology and Geothermal Research 54, 177-196.

Henry, C.D. and Wolff, J.A. 1992. Distinguishing strongly rheomorphic tuffs from extensive silicic lavas. Bulletin Volcanologique 54, 171-186.

Huhma, H., Claesson, S., Kinny, P.D. \& Williams, I.S. 1991. The growth of Early Proterozoic crust: new evidence from Svecofennian detrital zircons. Terra Nova 3, 175-179.

Kähkönen, Y. 1987. Geochemistry and tectonomagmatic affinities of the metavolcanic rocks of the early Proterozoic Tampere Schist Belt, southern Finland. Precambrian Research 35, 295-311.

Kähkönen, Y. 1989. Geochemistry and petrology of the metavolcanic rocks of the early Proterozoic Tampere Schist Belt, Southern Finland. Geological Survey of Finland, Bulletin 345. 104 p.

Kähkönen, Y. 1994. Shoshonitic and high-K metavolcanic rocks in the southern parts of the Paleoproterozoic Tampere Schist Belt, southern Finland: evidence for an evolved arc-type setting. Geological Survey of Finland, Special Paper 19, 101-115.

Kähkönen, Y. \& Huhma, H. 1993. An Archaean cobble in a Svecofennian conglomerate near Tampere, southern Finland. Geological Survey of Finland, Special Paper 18, 31-36.

Kähkönen, Y. \& Leveinen, J. 1994. Geochemistry of metasedimentary rocks of the Paleoproterozoic Tampere Schist Belt, southern Finland. Geological Survey of Finland, Special Paper 19, 117-136.

Kähkönen, Y. \& Nironen, M. 1994. Supracrustal rocks around the Paleoproterozoic Haveri $\mathrm{Au}-\mathrm{Cu}$-deposit, southern Finland: evolution from a spreading center to a volcanic arc environment. Geological Survey of Finland, Special Paper 19, 141-159.
Kähkönen, Y., Huhma, H. \& Aro, K. 1989. U-Pb zircon ages and $\mathrm{Rb}-\mathrm{Sr}$ whole-rock isotope studies of early Proterozoic volcanic and plutonic rocks near Tampere, southern Finland. Precambrian Research 45, 27-43.

Kilpeläinen, T., Korikovsky, S., Korsman, K. \& Nironen, M. 1994. Tectono-metamorphic evolution in the Tampere-Vammala area. Geological Survey of Finland, Guide 37, 27-34.

Kontinen, A. 1987. An early Proterozoic ophiolite - the Jormua mafic-ultramafic complex, northeastern Finland. Precambrian Research 35, 313-342.

Kousa, J., Marttila, E. \& Vaasjoki, M. 1994. Petrology, geochemistry and dating of Paleoproterozoic metavolcanic rocks in the Pyhäjärvi area, central Finland. In: Nironen, M. \& Kähkönen, Y. (eds.) Geochemistry of Proterozoic supracrustal rocks in Finland. Geological Survey of Finland, Special Paper 19, 7-27.

Lahtinen, R. 1996. Geochemistry of Palaeoproterozoic supracrustal and plutonic rocks in the Tampere-Hämeenlinna area, southern Finland. Geological Survey of Finland, Bulletin 389. 113 p.

Lahtinen, R. \& Huhma H. 1997. Isotopic and geochemical constraints on the evolution of the 1.93-1.79 Ga Svecofennian crust and mantle in Finland. Precambrian Research 82, 13-34.

Laitakari, I. 1980. Vulkaanisista primäärirakenteista. Geologi 32, 124-125.

Leveinen, J. 1990. Tampereen liuskevyöhykkeen kerrostumat Pulesjärven profiilissa. Unpublished master's thesis, University of Helsinki, Department of Geology. $134 \mathrm{p}$.

Mäkelä, K. 1980. Geochemistry and origin of Haveri and Kiipu, Proterozoic strata-bound volcanogenic gold-copper and zinc mineralizations from southwestern Finland. Geological Survey of Finland, Bulletin 310. 79 p.

Matisto, A. 1968. Die Meta-Arkose von Mauri bei Tampere. Bulletin de la Commission géologique de Finlande 235. $21 \mathrm{p}$.

Matisto, A. 1977. Tampereen kartta-alueen kallioperä. Summary: Precambrian rocks of the Tampere map-sheet area. Geological map of Finland 1: 100 000, Sheet 2123 Tampere. Espoo: Geological Survey of Finland. 50 p.

McPhie, J., Doyle, M. \& Allen, R. 1993. Volcanic Textures. A guide to the interpretation of textures in volcanic rocks. Hobart: Centre for Ore Deposition and Exploration Studies, University of Tasmania. $196 \mathrm{p}$.

Moore, J.C., Diebold, J., Fisher, M.A., Sample, J., Brocher, T., Taiwani, M., Ewing, J., von Huene, R., Rowe, C., Stone, D., Stevens, C. \& Sawyer, D. 1991. EDGE deep seismic reflection transect of the eastern Aleutian arctrench layered lower crust reveals underplating and continental growth. Geology 19, 420-424.

Nironen, M. 1989. The Tampere Schist Belt: structural style within an early Proterozoic volcanic arc system in southern Finland. Precambrian Research 43, 23-40.

Ojakangas, R.W. 1986. An Early Proterozoic metagraywacke-slate turbidite sequence: the Tampere schist belt, southwestern Finland. Bulletin of the Geological Soci- 
ety of Finland 58, 241-261.

Peltonen, P. Kontinen, A. \& Huhma, H. 1996. Petrology and geochemistry of metabasalts from the 1.95 Ga Jormua Ophiolite, northeastern Finland. Journal of Petrology $37,1359-1383$.

Rautio, T. 1987. Tampereen liuskejaksom litostratigrafia ja paleosedimentologia Kolunkylän ja Veittijärven alueilla. Unpublished master's thesis, University of Oulu, Department of Geology. 108 p.

Sederholm, J.J. 1897. Über eine archäische Sedimentformation im Südwestlichen Finland und ihre Bedeutung für die Erklärung der Enstehungsweise des Grundgebirges. Bulletin de la Commission géologique de Finlande 6. $254 \mathrm{p}$.

Seitsaari, J. 1951. The Tampere schist belt northeast of Tampere in Finland. Bulletin de la Commission géologique de Finlande 153. 120 p.
Simonen, A. 1953. Stratigraphy and sedimentation of the Svecofennidic early Archean supracrustal rocks in southwestern Finland. Bulletin de la Commission géologique de Finlande 160. 64 p.

Simonen, A. 1980. The Precambrian in Finland. Geological Survey of Finland, Bulletin 304. 58 p.

Simonen, A. \& Kouvo, O. 1951. Archean varved schists north of Tampere in Finland. Bulletin de la Commission géologique de Finlande 154, 93-114.

Wasström, A. 1993. The Knaften granitoids of Västerbotten Country, northern Sweden. In: Lundqvist, Th. (ed.) Radiometric dating results. Geological Survey of Sweden, Research Papers C 823, 60-64.

Welin, E., Christiansson, K. \& Kähr, A.-M. 1993. Isotopic investigations of metasedimentary and igneous rocks in the Palaeoproterozoic Bothnian Basin, central Sweden. Geologiska Föreningens i Stockholm Förhandlingar $115,285-296$. 